\title{
Nucleation of Biomimetic Hydroxyapatite
}

\author{
Božana Čolovićn , Dejan Marković2 ${ }^{2}$ Vukoman Jokanović1 \\ ${ }^{1}$ Laboratory for Radiation Chemistry and Physics, Institute of Nuclear Sciences "Vinča", Belgrade, Serbia; \\ ${ }^{2}$ Clinic for Pediatric and Preventive Dentistry, School of Dentistry, University of Belgrade, Belgrade, Serbia
}

\begin{abstract}
SUMMARY
Introduction The aim of the study was to assess the formation of biomimetic calcium hydroxyapatite (HAP) on the surface of different substrates.

Material and Methods Silica coated stainless steel tapes and thin polymer films (alginate, cellulose, poly lactide-coglycolide - PLGA) deposited on hydroxyapatite scaffold were used as substrate. Supersaturated simulated body fluid (SBF) and SBF combined with Fetal Calf Serum (FCS) or Eagle's Minimum Essential Medium (EMEM) were used as bioactive liquid medium where biomimetic nucleation of HAP occurred. Infrared spectroscopy with Fourier transformation was used to analyze the formed phases, while scanning electron microscopy indicated the morphology of nucleated phase.

Results The results of measuring the mass with volume adjustments done by the BET method showed that the thickness of the film of nucleated calcium hydroxyapatite depended on the time that samples spent soaked in SBF-in as well as the type of selected biomimetic medium.

Conclusion Biomimetic calcium hydroxyapatite is possible to produce by self nucleation on different substrates in the presence of simulating body fluid.
\end{abstract}

Keywords: biomimetic method; bioactive thin films; biomimetic hydroxyapatite; nanostructure design

\section{INTRODUCTION}

Nature has created materials with excellent functional characteristics, and science has focused on developing new methods of synthesis, which are able to mimic natural processes. The aim is not only to imitate the biological systems, but to use ideas inspired by them, to synthesize new materials. Biomimetic method was found suitable for synthesis modern materials of complex forms and hierarchical organization structure, adequate for use in biological systems $[1,2]$.

Biomimetic method can be used to form bioactive coatings on metallic implants that allow formation of appropriate bonds with surrounding bone [3-6]. Using biomimetic method, it is possible to produce apatite with similar structural and morphological characteristics as natural bone on the surface of implant. Since this method uses solutions with similar ionic composition as blood plasma, the conditions for hydroxyapatite (HAP) nucleation are similar to the natural [7-11]. The formation of HAP on the surface of metal can be accelerated by previous coating with thin layer of oxide $\left(\mathrm{SiO}_{2}, \mathrm{TiO}_{2}\right.$, with built $\mathrm{OH}$ groups within the oxide layer). Built $\mathrm{OH}$ groups serve as activators of heterogeneous apatite nucleation during deposition of calcium and phosphate ions from oversaturated simulated body fluid (SBF) $[12,13]$.

The aim of this study was to investigate the mechanism of HAP nucleation on the stainless steel tapes coated with a layer of $\mathrm{SiO}_{2}$, using $\mathrm{SBF}$ and $\mathrm{SBF}$ in combination with Fetal Calf Serum (FCS) or Eagle's Minimum Essential
Medium (EMEM) with positive effect on the kinetics of HAP nucleation due to the presence of amino groups. An additional objective was to examine the application of biomimetic methods in designing porous apatite carriers. Adequate nanotopology of interior walls of porous carriers is essential for normal cell growth, and it could be achieved by biomimetic treatment of these carriers in SBF, previously synthesized by any method. Polymers (PLGA, cellulose and alginate) were used for the functionalization of the walls of porous carrier in order to achieve a specific nanodesign during nucleation of HAP on their surface [14].

\section{MATERIALS AND METHODS}

The experimental part of the research included the preparation of simulating body fluid, preparation of the substrate, forming biomimetic HAP and characterization of nucleated HAP.

\section{Preparation of SBF}

SBF was prepared using slightly different instruction, in comparison to the original SBF, where the concentrations of individual ions were: $c\left(\mathrm{Cl}^{-}\right)=54 \mathrm{mmol} / \mathrm{dm}^{3} ; \mathrm{c}\left(\mathrm{Na}^{+}\right)=54.2$ $\mathrm{mmol} / \mathrm{dm}^{3} ; \mathrm{c}\left(\mathrm{Ca}^{2+}\right)=2.5 \mathrm{mmol} / \mathrm{dm}^{3} ; \mathrm{c}\left(\mathrm{PO}_{4}^{3-}\right)=1 \mathrm{mmol} /$ $\mathrm{dm}^{3} ; \mathrm{c}\left(\mathrm{Mg}^{2+}\right)=0.3 \mathrm{mmol} / \mathrm{dm}^{3} ; \mathrm{c}\left(\mathrm{NO}_{3}{ }^{-}\right)=0.6 \mathrm{mmol} / \mathrm{dm}^{3}$ and $c\left(\mathrm{~K}^{+}\right)=1,4 \mathrm{mmol} / \mathrm{dm}^{3}[10]$. Concentration of $\mathrm{PO}_{4}{ }^{3-}$ and 
$\mathrm{Ca}^{2+}$ ions were slightly higher, and concentrations of $\mathrm{Na}^{+}$ and $\mathrm{Cl}^{-}$ions slightly lower than in the original SBF, while the $\mathrm{pH}$ value was adjusted to 7.4.

\section{Preparation of substrate}

\section{$\mathrm{SiO}_{2}$ substrate}

Silica films were deposited on the tapes of stainless steel (Sandvik OC 404, thickness $35 \mu \mathrm{m}$, width $3 \mathrm{~cm}$, length 10 $\mathrm{cm}$ ) using dual fluid dispensing nozzle. The solution of $\mathrm{SiO}_{2}$ in concentration of $13.5 \%$ was used as a precursor. The thickness of the deposited $\mathrm{SiO}_{2}$ film was $22.5 \mu \mathrm{m}$ [15].

\section{Polymer substrate}

Substrate for biomimetic deposition of HAP was prepared as follows: a thin layer of granules of porous HAP (size 300 $\mu \mathrm{m}$ ) obtained by polymeric foam was applied on the glass plates and a thin film of alginate, cellulose or PLGA was applied over the apatite layer. Before application, alginate and cellulose were dissolved in water and PLGA in chloroform, in order to obtain solutions of concentration $1 \% \mathrm{w} / \mathrm{w}$.

\section{Formation of biomimetic HAP}

Stainless steel tapes with deposited $\mathrm{SiO}_{2}$ film were cut into pieces, the first part was put in SBF, the second part in SBF with addition of Fetal Calf Serum (FCS), while the third part was soaked in SBF with addition of Eagle's Minimum Essential Medium (EMEM). The samples were soaked in SBF for 10, 14, 20, 33 and 43 days. During that time, a self nucleation of HAP occurred on the surface of submerged parts. Tiles with inflicted HAP and polymer films were then immersed in SBF and kept for 6 weeks at room temperature. After removing from the medium, the

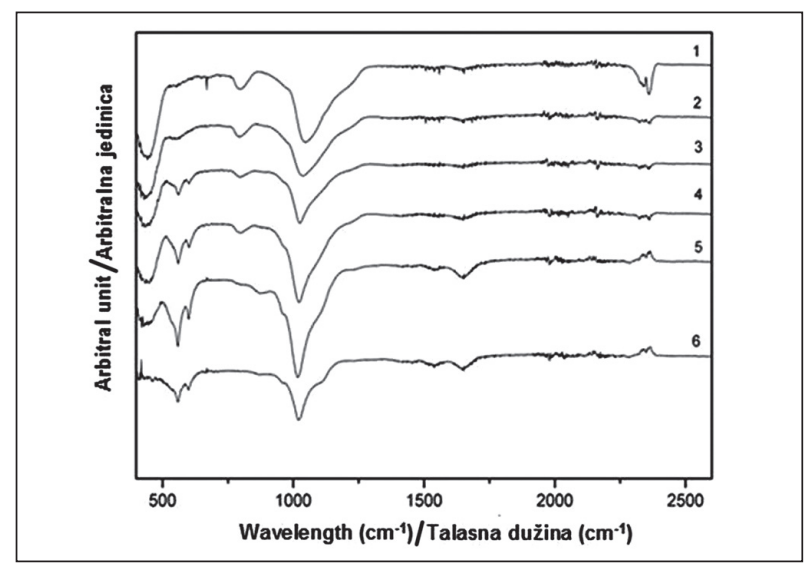

Figure 1. IR spectra of nucleated apatite film after various time of sample soaking in SBF

Slika 1. IR spektri nukleiranog apatitnog filma nakon različitog vremena držanja u SBF

1 - 10 days; 2 - 20 days; 3 - 33 days; 4 - 43 days; 5 - 14 days, EMEM added; $6-14$ days, FCS added

1 - 10 dana; 2 - 20 dana; 3 - 33 dana; 4 - 43 dana; 5 - 14 dana, dodatak EMEM; 6 - 14 dana, dodatak FCS samples were rinsed with deionized water and obtained phases were analyzed.

\section{Methods of characterization of nucleated HAP}

Phases nucleated on the surface of both types of substrate were analyzed by FTIR-ATR method (Nicollet 380 FT-IR, Thermo Electron Corporation). The morphology and structure of films of nucleated HAP were analyzed by SEM microscopy.

BET method showed that the thickness of the film of nucleated calcium hydroxyapatite depended on time that samples spent in SBF, and addition of FCS and EMEM to SBF medium increased the speed of HAP nucleation.

\section{RESULTS AND DISCUSSION}

\section{FTIR analysis}

\section{$\mathrm{SiO}_{2}$ substrate}

Figure 1 shows the FTIR spectra of nucleated apatite film after different time of soaking in SBF. The bands visible on the spectrum at $2340 \mathrm{~cm}^{-1} \mathrm{can}$ be attributed to the stretching vibrations of $\mathrm{OH}$ - groups located at the ends of $\mathrm{SiO}_{2}$ chains. The bands from 1643 to $1649 \mathrm{~cm}^{-1}$ correspond to the bending vibrations of $\mathrm{OH}^{-}$groups from $\mathrm{SiO}_{2}$ chains and HAP and the bands from 600 to $662 \mathrm{~cm}^{-1}$ correspond to the vibrations of free $\mathrm{OH}^{-}$groups. The bands between 1018 and $1043 \mathrm{~cm}^{-1}$ correspond to the transverse asymmetric vibrations of $\mathrm{Si}-\mathrm{O}-\mathrm{Si}$ chains, and the bands from 791 to $802 \mathrm{~cm}^{-1}$ belong to the swinging vibration of Si-O-Si chains, while the bands from 432 to $451 \mathrm{~cm}^{-1}$ correspond to the transverse swinging vibrations of $\mathrm{Si}-\mathrm{O}-\mathrm{Si}$ chains. The bands that appear at 1018 to $1043 \mathrm{~cm}^{-1}$ belong to the asymmetric stretch vibration of $\mathrm{PO}_{4}{ }^{3-}$ groups, while the bands at 550 to $563 \mathrm{~cm}^{-1}$ originate from $v 2$ stretching symmetric vibrations. The bands at 432 to $451 \mathrm{~cm}^{-1}$ belong partly to $v 2$ symmetrical vibration of $\mathrm{PO}_{4}{ }^{3-}$ groups [15].

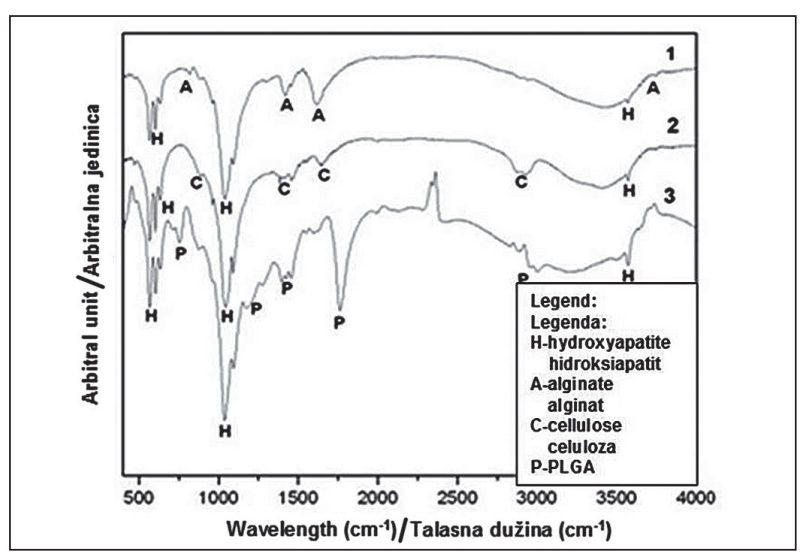

Figure 2. IR spectra of nucleated apatite film on different polymer substrates

Slika 2. IR spektri nukleiranog apatitnog filma na različitim polimernim supstratima

1 - alginate; 2 - cellulose; 3 - PLGA

1 - alginat; 2 - celuloza; 3 - PLGA 


\section{Polymer substrate}

By analyzing the FTIR spectra, it was concluded that the phase biomimetically formed on the surface of HAP/ polymer composite is hydroxyapatite with shifted steichiometry (Figure 2). All three IR spectra in Figure 2 show the characteristic bands for HAP: a weak peak that corresponds to the stretching $\mathrm{OH}^{-}$groups was observed at about $3570 \mathrm{~cm}^{-1}$; the bands at about $1640 \mathrm{~cm}^{-1}$ correspond to the bending vibrations of $\mathrm{OH}^{-}$groups, and the bands at 600 to $650 \mathrm{~cm}^{-1}$ correspond to the vibrations of free OH-groups; the bands that were reported at 970-1090 $\mathrm{cm}^{-1}$ belong to the asymmetric stretch vibrations of $\mathrm{PO}_{4}^{3-}$ groups, while the bands at 550 to $640 \mathrm{~cm}^{-1}$ originate from the symmetric stretching vibrations of $\mathrm{PO}_{4}^{3-\text {-groups; the }}$ bands at 430 to $450 \mathrm{~cm}^{-1}$ belong partly to $v 2$ symmetric vibrations of $\mathrm{PO}_{4}{ }^{3-}$ groups.

The bands characteristic for each polymer were also present in the corresponding IR spectra:

- Alginate

The bands present at about $3500-3700 \mathrm{~cm}^{-1}$ are attributed to the stretching OH-groups; the bands from 1615 to $1420 \mathrm{~cm}^{-1}$ correspond to the asymmetric and symmetric stretching of $\mathrm{COO}^{-}$groups, respectively; the bands at about $1640 \mathrm{~cm}^{-1}$ can be attributed to water bonded to the polymer; the bands at about $1300 \mathrm{~cm}^{-1}$ correspond to the vibrations of the polymer chain; the bands that belong to
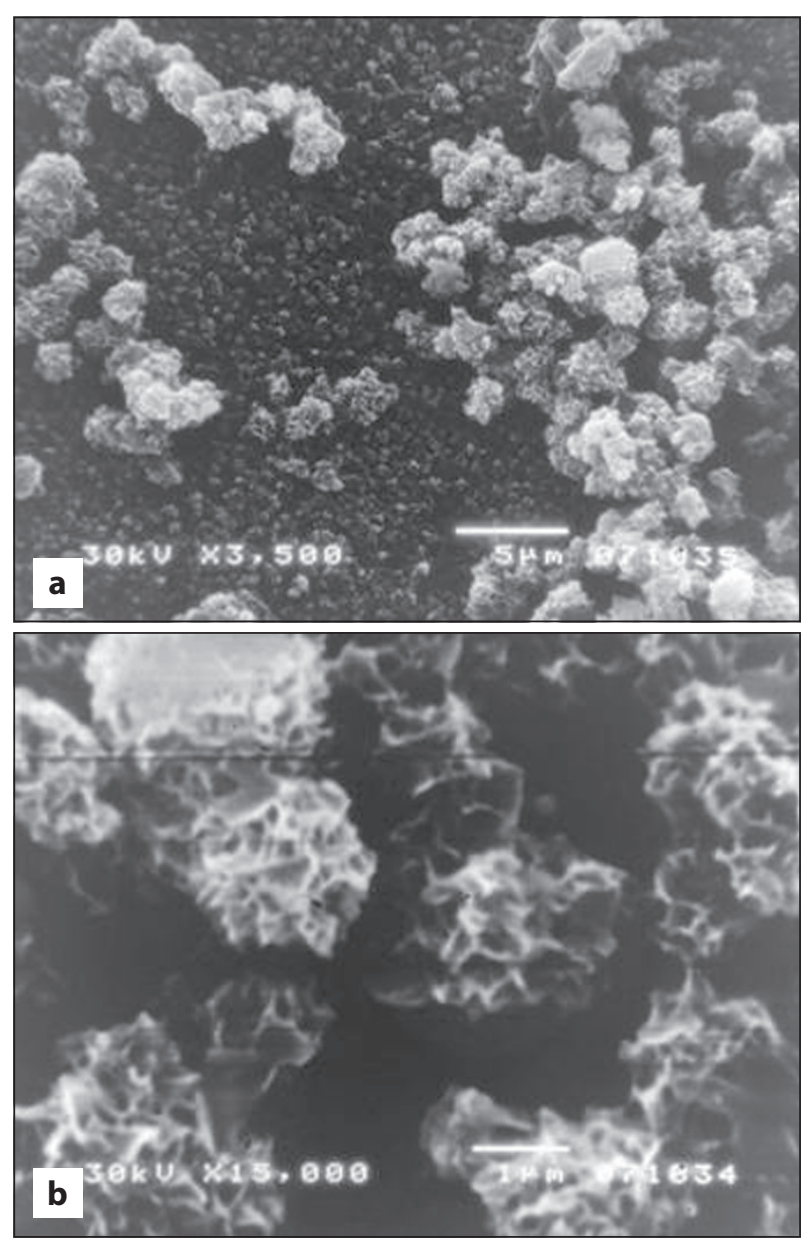

Figure 3a-b. SEM micrographs of nucleated apatite film on $\mathrm{SiO}_{2}$ Slika 3a-b. SEM snimci nukleiranog apatitnog filma na $\mathrm{SiO}_{2}$ the asymmetric stretching of C-O-C at about 1080-1020 $\mathrm{cm}^{-1}$ are partially hidden by the bands that correspond to the apatite; the bands present at about $820 \mathrm{~cm}^{-1}$ are attributed to the combination of the following vibrations: bending vibrations - $\mathrm{CCO}$, and $-\mathrm{CCH}$ groups and twisted vibrations of $\mathrm{C}=\mathrm{O}$ group $[16,17]$.

- Cellulose

The bands at 2920 and $2940 \mathrm{~cm}^{-1}$ correspond to the stretching of $\mathrm{C}=\mathrm{O}$ and $\mathrm{C}-\mathrm{H}$ groups, respectively; the bands around $2900 \mathrm{~cm}^{-1}$ belong to $\mathrm{O}-\mathrm{H}$ stretching; while the bands at $1640 \mathrm{~cm}^{-1}$ correspond to $\mathrm{O}-\mathrm{H}$ bending of absorbed water; the bands at $1590 \mathrm{~cm}^{-1}$ confirm the presence of $\mathrm{COO}^{-}$ groups; the bands at about $1430 \mathrm{~cm}^{-1}$ are attributed to $\mathrm{HCH}$ and $\mathrm{OCH}$ bending deformation in the plane, while the band at about $1380 \mathrm{~cm}^{-1}$ corresponds to $\mathrm{C}-\mathrm{H}$ bending; the bands at about $900 \mathrm{~cm}^{-1}$ belong to the $\mathrm{COC}, \mathrm{CCO}$, and $\mathrm{CCH}$ deformation and stretched vibrations, which correspond to the shifts of C-5 and C-6 atoms [18, 19].

- PLGA

The bands recorded at $2995 \mathrm{~cm}^{-1}$ correspond to asymmetric $\mathrm{C}-\mathrm{H}$ stretching while the bands at about 2950 and $2880 \mathrm{~cm}^{-1}$ belong to $\mathrm{C}-\mathrm{H}$ symmetric stretching; the expressed band at $1760 \mathrm{~cm}^{-1}$ is attributed to $\mathrm{C}=0$ stretching; the bands at about $1100-1280 \mathrm{~cm}^{-1}$ correspond to C-O-C stretching, the bands observed from 1400 to 1500 $\mathrm{cm}^{-1}$ correspond to $\mathrm{CH}_{2}, \mathrm{CH}_{3}$, and $\mathrm{CH}$ deformations; the band at about $750 \mathrm{~cm}^{-1}$ belongs to the swinging vibrations of long $\mathrm{CH}_{2}$ chain $[20,21]$.

\section{SEM study}

\section{$\mathrm{SiO}_{2}$ substrate}

Figures $3 \mathrm{a}$ and $3 \mathrm{~b}$ clearly show the nucleation of apatite by sedimentation of the layers, one on another up to the final thickness of apatite film. Clear morphology of nucleated particles, shaped as dandelion flower and mean diameter of about $1 \mu \mathrm{m}$ is observed.

\section{Polymer substrates}

SEM images showed strongly developed morphology of HAP particles (Figures 4a-b, 5a-b and 6a-b).

As shown in Figures 4a and 4b, HAP particles nucleated on alginate are present in two forms-the form of dandelion flower and a polygonal shape. Particles of polygonal shape are smaller; the diameter of the smallest particle is about $1 \mu \mathrm{m}$, while the greatest dimension is about 5 $\mu \mathrm{m}$. Size distribution of the particles of dandelion shape is from 3 to $5 \mu \mathrm{m}$. Width of needle-shaped structures on the surface of these particles is only $18-25 \mathrm{~nm}$, while the distance between them is $150-500 \mu \mathrm{m}$.

The diverse morphology of hydroxyapatite particles nucleated on cellulose is shown in Figures 5a and 5b. Mean particle size is about $3 \mu \mathrm{m}$ while the smallest particle size is about $1 \mu \mathrm{m}$. Needle and plate- shaped structures are visible on the surface of particles and their width is from 30 to $150 \mathrm{~nm}$. 

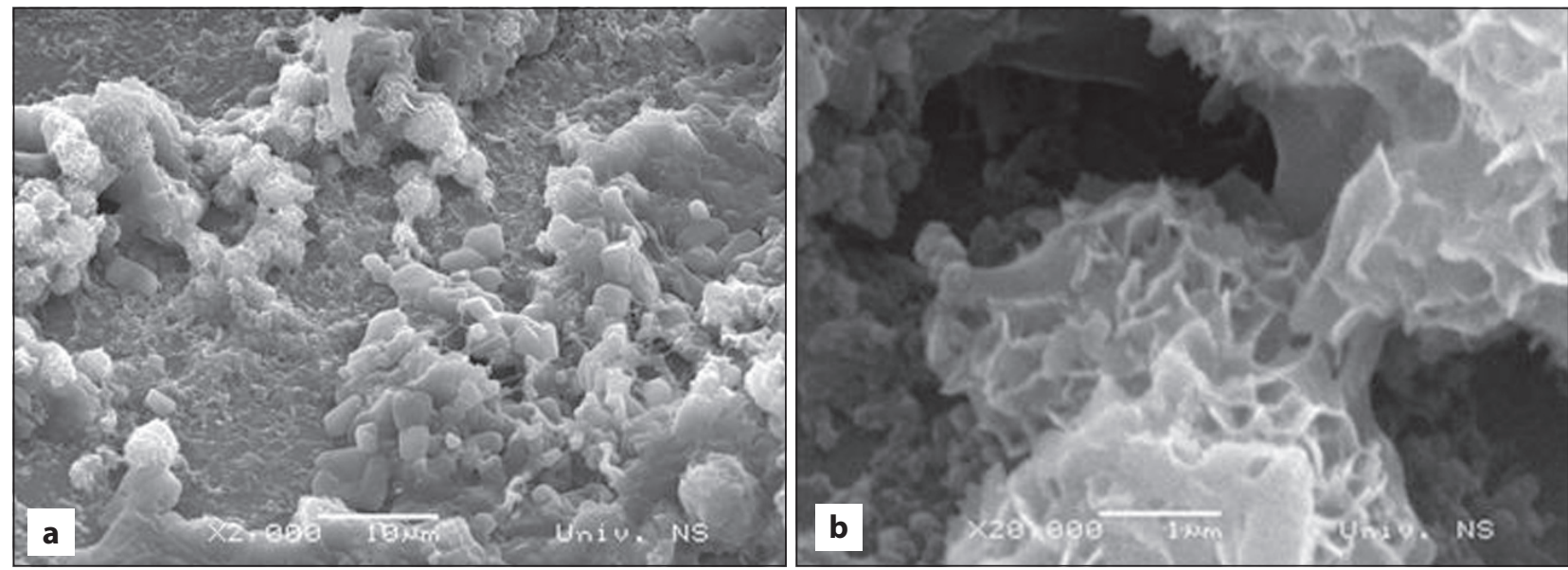

Figure 4a-b. SEM micrographs of nucleated apatite film on alginate Slika 4a-b. SEM snimci nukleiranog apatitnog filma na alginatu
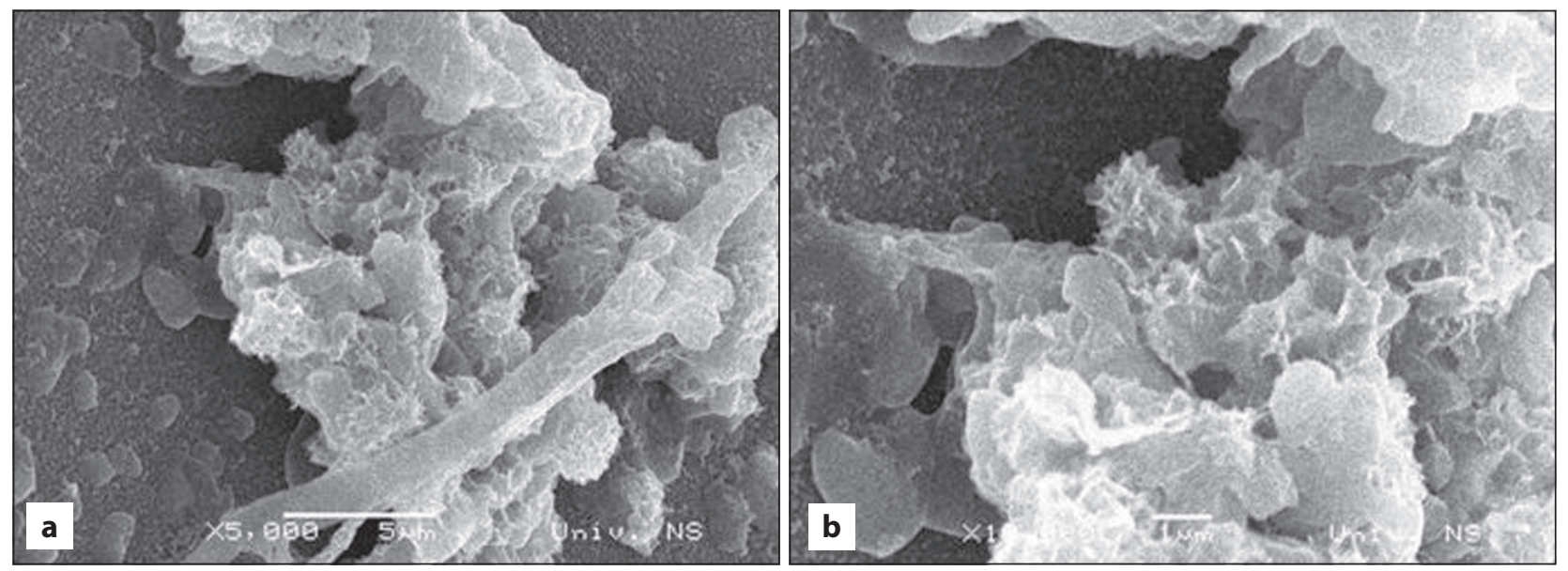

Figure 5a-b. SEM micrographs of nucleated apatite film on cellulose Slika 5a-b. SEM snimci nukleiranog apatitnog filma na celulozi
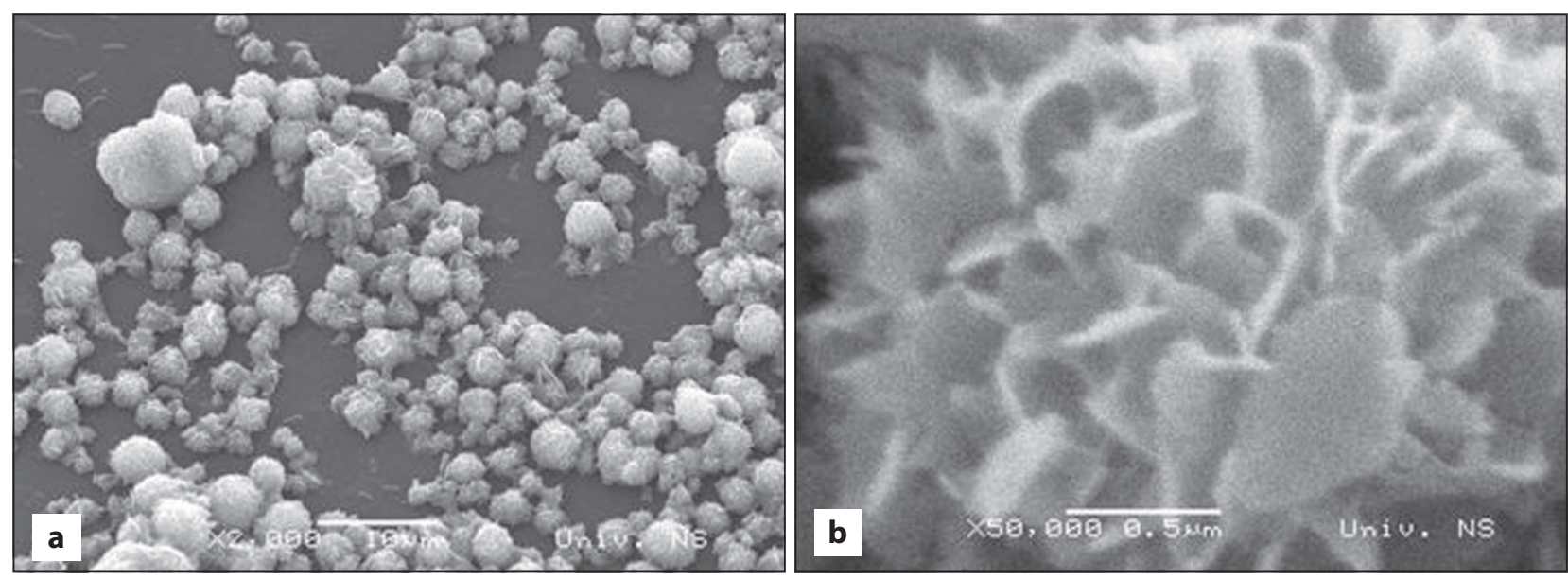

Figure $\mathbf{6 a}-\mathbf{b}$. SEM micrographs of nucleated apatite film on PLGA Slika 6a-b. SEM snimci nukleiranog apatitnog filma na PLGA

Apatite nucleated on the surface of PLGA film is shown on SEM images on Figures 6a and 6b. Particles are shaped as dandelion flower with a highly developed surface morphology and the petal-shaped structure. The particle size is generally $2.5-3.5 \mu \mathrm{m}$, but the finer particles are also present $(0.7-1.5 \mu \mathrm{m})$, as well as a lower number of larger particles $(4.3-8.5 \mu \mathrm{m})$. Width of petal-shaped structure on the surface of the particles is $15-20 \mathrm{~nm}$.

\section{Film thickness of nucleated HAP}

Based on measurements of weight and pore volume using Lecloux and Pirard method, the thickness of nucleated apatite films was determined [15]. The thickness of nucleated apatite film depended on the duration of soaking in SBF, as well as the type of used medium (Table 1). 
Table 1. Thicknesses of self nucleated apatite film after various periods of nucleation

Tabela 1. Debljina samonukleiranog apatitnog filma posle različitih perioda nukleacije

\begin{tabular}{|c|c|c|c|c|c|c|}
\hline $\begin{array}{c}\text { Thickness of } \\
\mathrm{SiO}_{2} \text { film }(\mu \mathrm{m}) \\
\mathrm{Debljina} \mathrm{SiO}_{2} \\
\text { filma }(\mu \mathrm{m})\end{array}$ & $\begin{array}{l}\text { Medium } \\
\text { Medijum }\end{array}$ & $\begin{array}{c}\text { Time of apatite } \\
\text { nucleation (days) } \\
\text { Vreme nukleacije } \\
\text { apatita (dani) }\end{array}$ & $\begin{array}{l}\text { The mass of } \\
\text { apatite film (mg) } \\
\text { Masa apatitnog } \\
\text { filma (mg) }\end{array}$ & $\begin{array}{c}\text { Specific area } \\
\left(\mathrm{m}^{2} / \mathrm{g}\right) \\
\text { Specifična } \\
\text { površina }\left(\mathrm{m}^{2} / \mathrm{g}\right)\end{array}$ & $\begin{array}{l}\text { Volume of pore } \\
\left(\mathrm{cm}^{3} / \mathrm{g}\right) \\
\text { Zapremina pora } \\
\left(\mathrm{cm}^{3} / \mathrm{g}\right)\end{array}$ & $\begin{array}{c}\text { Thickness of } \\
\text { apatite film }(\mu \mathrm{m}) \\
\text { Debljina apatitnog } \\
\text { filma }(\mu \mathrm{m})\end{array}$ \\
\hline \multirow{6}{*}{22.5} & \multirow{4}{*}{ SBF } & 10 & 0.2 & - & - & - \\
\hline & & 20 & 0.6 & 94 & 0.116 & 2.7 \\
\hline & & 33 & 1.2 & 102 & 0.107 & 4.9 \\
\hline & & 43 & 1.4 & 112 & 0.097 & 6.2 \\
\hline & $\mathrm{SBF}+\mathrm{EMEM}$ & 14 & 1.3 & 110 & 0.100 & 4.8 \\
\hline & $\mathrm{SBF}+\mathrm{FCS}$ & 14 & 1.1 & 105 & 0.110 & 4.1 \\
\hline
\end{tabular}

\section{The mechanism of HAP formation}

\section{$\mathrm{SiO}_{2}$ substrate}

When stainless steel tapes with $\mathrm{SiO}_{2}$ coatings are sunk in SBF, HAP self nucleation happens on their surface. It is caused by presence of $\mathrm{Na}^{+}$ions in $\mathrm{SBF}$, which incorporate in nanopores of $\mathrm{SiO}_{2}$ film leading to local $\mathrm{pH}$ rise on the film surface, supporting the heterogeneous nucleation of HAP by the reaction [22]:

$$
10 \mathrm{Ca}^{2+}{ }_{(\mathrm{aq})}+6 \mathrm{PO}_{4}{ }^{3-}{ }_{(\mathrm{aq})}+2 \mathrm{OH}^{-}{ }_{(\mathrm{aq})}=\mathrm{Ca}_{10}\left(\mathrm{PO}_{4}\right)_{6}(\mathrm{OH})_{2(\mathrm{~s})}
$$

Firstly, positive $\mathrm{Ca}^{2+}$ ions are attracted to the surface of $\mathrm{SiO}_{2}$ films due to the presence of $\mathrm{Si}-\mathrm{OH}$ groups, and then, they are attracted to negatively charged $\mathrm{PO}_{4}{ }^{3-}$ ions, which lead to the formation of calcium phosphate. When $\mathrm{HAP}$ is formed on the surface of the $\mathrm{SiO}_{2}$ film, further nucleation occurs spontaneously because the activation energy for heterogeneous nucleation on the surface is less than the activation energy for homogeneous nucleation in the solution [23]. The nucleated apatite film is growing by simultaneous attraction of calcium and phosphate ions from SBF.

Addition of FCS and EMEM to SBF, beside nucleation which mechanism is already described, gave a significant influence of amino group in FCS and sections of charged proteins in EMEM. They acted as additional and very effective nucleation centers due to their polar effect, and according to the mechanism "PILP" (polymer induced liquid precursor) caused rapid nucleation of apatite through the process of binding $\mathrm{Ca}^{2+}$ in the given active centers, and then simultaneous binding of $\mathrm{PO}_{4}^{3-}$ ions.

\section{Polymer substrates}

Carboxyl/hydroxyl groups of alginate, cellulose and PLGA chains act as active centers which initiate nucleation. These negatively charged groups, in the initial stage of nucleation, were attracted by $\mathrm{Ca}^{2+}$ ions from SBF, which were then attached on the polymer surface. In the next step, $\mathrm{PO}_{4}{ }^{3-}$ ions were attracted to the positive $\mathrm{Ca}^{2+}$ ions. The process of calcium phosphate nucleation occured by synchronized attaching $\mathrm{Ca}^{2+}$ ions on active sites of corresponding polymer and simultaneous attachment of $\mathrm{PO}_{4}{ }^{3-}$ ions on $\mathrm{Ca}^{2+}$ ions. As shown in some studies, the concentration of carboxyl/hydroxyl groups on the polymer surface the most likely had a significant effect on speed and mechanism of calcium phosphate nucleation [24, 25]. The density of nucleation sites can also affect the size of agglomerates and their morphology, as confirmed by the results in the current study. The highest density of nucleated particles was observed with alginate (Figure 4a-b), which was probably caused by high density of carboxyl and hydroxyl groups in alginate chains. In the case of nucleation on PLGA (Figure 6a-b) which contains significantly lower number of carboxylic groups than alginate, the density of nucleated particles was also lower. The spatial distribution of hydroxyl groups in cellulose chains revealed that they were relatively close to each other. Therefore, the agglomerates of neighboring nucleation sites bonded to each other and formed elongated structures, as shown in Figures $5 \mathrm{a}$ and $5 \mathrm{~b}$. In the samples where alginate and cellulose were used, the smaller particles $(1-5 \mu \mathrm{m})$ were formed, possibly due to larger number of nucleation sites. In the case of PLGA, larger agglomerates were obtained (some bigger than $8 \mu \mathrm{m}$ ), which can be attributed to the smaller number of nucleation sites that caused further growth of apatite nucleus.

\section{CONCLUSION}

This study demonstrated the possibility of forming biomimetic calcium hydroxyapatite by self nucleation on different substrates in the presence of $\mathrm{SBF}$. When $\mathrm{SiO}_{2}$ or apatite porous carriers coated with polymer films were used as substrate, after a certain time spent in SBF, the presence of HAP on their surface was confirmed by FTIR-ATR method. SEM microscopy determined the structure of self nucleated apatite film. By measuring the mass with volume adjustments using BET method, it was shown that the thickness of nucleated film depended on the time that tapes were soaked in SBF. The addition of FCS and EMEM increased the velocity of apatite self nucleation.

\section{ACKNOWLEDGMENT}

This work was funded by the Ministry of Science and Technological Development of Serbia (Project no. 172026). 


\section{REFERENCES}

1. Xu AW, Ma Y, Cölfen H. Biomimetic mineralization. J Mater Chem. 2007; 17:415-49.

2. Dujardin E, Mann S. Bio-inspired materials chemistry. Adv Mater. 2002; 14:775-88.

3. Niinomi M. Recent metallic materials for biomedical applications. Metall Mater Trans A. 2002, 33:477-86.

4. Webster T). Nanophase ceramics: the future of orthopedic and dental implant material. In: Ying JY. Nanostructured Materials. New York: Academic Press; 2001. p.125-166.

5. Kokubo T, Takadama H. How useful is SBF in predicting in vivo bone bioactivity? Biomaterials. 2006; 27:2907-15.

6. Le Geros RZ. Properties of osteoconductive biomaterials: calcium phosphates. Clin Orthop Relat Res. 2002; 395:81-98.

7. Tas AC. Synthesis of biomimetic Ca-hydroxyapatite powders at $37^{\circ} \mathrm{C}$ in synthetic body fluids. Biomaterials. 2000; 21:1429-38.

8. Barrere F, van der Valk CM, Dalmeijer RAJ, van Blitterswijk CA, de Groot K, Layrolle P. In vitro and in vivo degradation of biomimetic octacalcium phosphate and carbonate apatite coatings on titanium implants. J Biomed Mater Res. 2003; 64:378-87.

9. Uchida M, Kim HM, Kokubo T, Nakamura T. Bonelike apatite formation induced on zirconia gel in simulated body fluid and its modified solutions. J Am Ceram Soc. 2001; 84:2041-4.

10. Oyane A, Kim HK, Furuya T, Kokubo T, Miyazaki T, Nakamura T. Preparation and assessment of revised simulated body fluids. J Biomed Mater Res. 2003; 65A:188-95.

11. Bigi A, Boanini E, Bracci B, Facchini A, Panzavolta S, Segatti F, et al. Nanocrystalline hydroxyapatite coatings on titanium: a new fast biomimetic method. Biomaterials. 2005; 26:4085-9.

12. Hench LL. In: Yamamoro T, Hench LL, Wilson J, editors. CRC Handbook of Bioactive Ceramics. Vol. 1. Boca Raton, FL: CRC; 1990. p.7.

13. Li P, Ohtsuki C, Kokubo T, Nakanishi K, Soga N, Nakamura T, et al. A role of hydrated silica, titania and alumina in forming biologically active bone-like apatite on implant. J Biomed Mater Res. 1994; 28:7-15.

14. Kokubo T. Apatite formation on surfaces of ceramics, metals and polymers in body environment. Acta Mater. 1998; 46:2519-27.

15. Čolović B, Jokanović V, Marković-Todorović B, Marković Z. AFM investigations of calcium hydroxyapatite thin films on the surface of thin silica films. Journal of Optoelectronics and Advanced Materials. 2009; 11:70-5.

16. Dupuy B, Arien A, Minnot AP. FT-IR membranes made with alginate/polylysine complexes. Variations with mannuronic or guluronic content of the polysaccharides. Art Cells Blood Substit Immobil Biotechnol. 1994; 22:71-82

17. Lawrie G, Keen I, Drew B, Chandler-Temple A, Rintoul L, Fredericks P, et al. Interactions between alginate and chitosan biopolymers characterized using FTIR and XPS. Biomacromolecules. 2007; 8:2533-41.

18. Zhbankov RG, Firsov SP, Buslov DK, Nikonenko NA, Marchewka MK, Ratajczak H. Structural physico-chemistry of cellulose macromolecules. Vibrational spectra and structure of cellulose. J Mol Struct. 2002; 614:117-25.

19. Oh SY, Yoo DI, Shin Y, Seo G. FTIR analysis of cellulose treated with sodium hydroxide and carbon dioxide. Carbohydr Res. 2005; 340:417-28.

20. Petricca SE, Marra KG, Kumta PN. Chemical synthesis of poly(lacticco-glycolic acid)/hydroxyapatite composites for orthopedics applications. Acta Biomater. 2006; 2:277-86.

21. Tai H, Upton CE, White L), Pini R, Storti G, Mazzotti M, et al. Studies on the interactions of $\mathrm{CO} 2$ with biodegradable poly(DL-lactic acid) and poly(lactic acid-co-glycolic acid) copolymers using high pressure ATR-IR and high pressure rheology. Polymer. 2010; 51:1425-31.

22. Cheng X, Nie B, Kumar S. Preparation and bioactivity of $\mathrm{SiO}_{2}$ functional films on titanium by PACVD. Trans Nonferrous Met Soc China. 2008; 18:627-30.

23. Li P, Kangasniemi I, de Grot K, Kokubo T. Bonelike hydroxyapatite induction by a gel-derived titania on titanium substrate. J Am Ceram Soc. 1994; 17:1307-12.

24. Nge T, Sugiyama J. Surface functional group dependent apatite formation on bacterial cellulose microfibrils network in a simulated body fluid. J Biomed Mater Res A. 2007; 81:124-34.

25. Hashizume M, Horii H, Kikuchi Jl, Kamitakahara M, Ohtsuki C, Tanihara M. Effects of surface carboxylic acid groups of cerasomes, morphologically stable vesicles having a silica surface, on biomimetic deposition of hydroxyapatite in body fluid conditions. J Mater Sci Mater Med. 2010; 2:111-9.

Received: 05/11/2010 • Accepted: 09/02/2011 


\title{
Nukleacija biomimetskog hidroksiapatita
}

\author{
Božana Čolović1, Dejan Marković2, Vukoman Jokanović1 \\ 'Laboratorija za radijacionu hemiju i fiziku, Institut za nuklearne nauke „Vinča”, Beograd, Srbija; \\ ${ }^{2}$ Klinika za dečju i preventivnu stomatologiju, Stomatološki fakultet, Univerzitet u Beogradu, Beograd, Srbija
}

\begin{abstract}
KRATAK SADRŽAJ
Uvod Cilj ovog rada je bio da se ispita formiranje biomimetskog kalcijum-hidroksiapatita na površinama različitih supstrata.

Materijal i metode rada Kao supstrati su korišćeni tanki filmovi silicijum-dioksida naneti na čelične trake i tanki polimerni filmovi (alginat, celuloza, polilaktidkoglikolid) naneti na visokoporozni hidroksiapatitni nosač. Simulirana telesna tečnost (engl. simulated body fluid - SBF), kao i SBF kombinovan sa serumom iz fetusa govečeta ili Iglovim medijumom korišćeni su kao bioaktivni tečni medijum u kojem se odvija biomimetska nukleacija apatita. Za analizu formiranih faza korišćena je infracrvena spektroskopija sa Furijeovom transformacijom, dok je skening elektronska mikroskopija ukazivala na morfologiju nukleirane faze.

Rezultati Merenje mase uz korekciju zapremine primenom metode BET pokazalo je da debljina filma nukleiranog kalcijum-hidroksiapatita zavisi od vremena držanja uzoraka u SBF, kao i od vrste izabranog biomimetskog medijuma.

Zaključak Dobijanje biomimetskog kalcijum-hidroksiapatita moguće je samonukleacijom na različitim supstratima i primenom SBF.
\end{abstract}

Ključne reči: biomimetska metoda; bioaktivni tanki filmovi; biomimetski hidroksiapatit; dizajniranje nanostrukture

\section{UVOD}

Priroda je stvorila materijale s odličnim funkcionalnim osobinama, a nauka se usmerila ka razvijanju novih načina sinteze koji treba da oponašaju prirodne procese. Glavni cilj nije samo u tome da se imitiraju određeni biološki sistemi, već da se iskoriste njima inspirisane ideje, kako bi se stvorili novi materijali. Biomimetska metoda se pokazala pogodnom za sintezu savremenih materijala složenog oblika i hijerarhijske strukturne organizacije, koji su adekvatni za primenu u biološkim sistemima $[1,2]$.

Biomimetska metoda može da se iskoristi kao jedna od metoda za dobijanje bioaktivnih prevlaka na metalnim implantatima koje omogućuju formiranje adekvatne veze s okolnom kosti [3-6]. Biomimetskom metodom se na površini metalnog implantata dobija apatit sličnih strukturnih i morfoloških odlika kao i prirodna kost, s obzirom na to da je ova metoda zasnovana na korišćenju rastvora sličnog jonskog sastava kao krvna plazma, pa su i uslovi nukleacije hidroksiapatita (HAP) slični prirodnim [7-11]. Formiranje HAP na površini metala može se ubrzati prethodnim prevlačenjem površine metala tankim slojem oksida $\left(\mathrm{SiO}_{2}, \mathrm{TiO}_{2}\right.$, sa ugrađenim $\mathrm{OH}$-grupama unutar oksidnog sloja). Ugrađene OH-grupe služe kao aktivatori heterogene nukleacije apatita prilikom taloženja kalcijumovih i fosfatnih jona iz presićene simulirane telesne tečnosti (engl. simulated body fluid-SBF) [12, 13].

Cilj ovog rada je bio da se prouči mehanizam nukleacije HAP na čeličnim trakama presvučenim slojem $\mathrm{SiO}_{2}$ koristeći $\mathrm{SBF}$, kao i SBF u kombinaciji sa fetusom govečeta (engl. fetal calf serum - FCS) ili Iglovim medijumom (engl. Eagle’s Minimum Essential Medium - EMEM), koji usled zastupljenosti amino-grupa povoljno utiču na kinetiku nukleacije HAP. Pored navedenog, dodatni cilj je bio da se ispita primena biomimetske metode za dodatno dizajniranje poroznih apatitnih nosača. Adekvatna nanotopologija unutrašnjih zidova poroznih nosača je bitna za normalan rast ćelija, i ona bi se mogla postići biomimetskim tretmanom ovih nosača u SBF, prethodno sintetisanih bilo kojom metodom. Polimeri (celuloza, alginat, polilaktidkoglikolid - PLGA) su korišćeni za funkcionalizaciju zidova poroznih nosača kako bi se postigao specifičan nanodizajn prilikom nukleiranja HAP na njihovu površinu [14].

\section{MATERIJAL I METODE RADA}

Eksperimentalni deo istraživanja je obuhvatio pripremu SBF, pripremu supstrata, formiranje biomimetskog HAP, odnosno karakterizaciju nukleiranog HAP.

\section{Priprema SBF}

SBF je pripremljen po nešto izmenjenoj recepturi u odnosu na originalni SBF, pri čemu su koncentracije pojedinih jona bile: $\mathrm{c}\left(\mathrm{Cl}^{-}\right)=54 \mathrm{mmol} / \mathrm{dm}^{3} ; \mathrm{c}\left(\mathrm{Na}^{+}\right)=54,2 \mathrm{mmol} / \mathrm{dm}^{3} ; \mathrm{c}\left(\mathrm{Ca}^{2+}\right)=2,5$ $\mathrm{mmol} / \mathrm{dm}^{3} ; \mathrm{c}\left(\mathrm{PO}_{4}{ }^{3-}\right)=1 \mathrm{mmol} / \mathrm{dm}^{3} ; \mathrm{c}\left(\mathrm{Mg}^{2+}\right)=0,3 \mathrm{mmol} / \mathrm{dm}^{3}$; $\mathrm{c}\left(\mathrm{NO}_{3}{ }^{-}\right)=0,6 \mathrm{mmol} / \mathrm{dm}^{3}$ i $\mathrm{c}\left(\mathrm{K}^{+}\right)=1,4 \mathrm{mmol} / \mathrm{dm}^{3}$ [10]. Koncentracije $\mathrm{PO}_{4}{ }^{3-}$ i Ca ${ }^{2+}$ jona su bile nešto veće, a koncentracije $\mathrm{Na}^{+} \mathrm{i}$ $\mathrm{Cl}^{-}$jona nešto manje nego kod originalnog SBF, dok je $\mathrm{pH}$ vrednost SBF podešena na 7,4 .

\section{Priprema supstrata}

\section{$\mathrm{SiO}_{2}$ supstrat}

Filmovi silicijum-dioksida deponovani su na trake od nerđajućeg čelika (Sandvik OC 404, debljina $35 \mu \mathrm{m}$, širina $3 \mathrm{~cm}$, dužina $10 \mathrm{~cm}$ ) koristeći dvofluidnu mlaznicu za raspršavanje. Kao prekursor je korišćen rastvor $\mathrm{SiO}_{2}$ u koncentraciji od 13,5\%. Debljina deponovanog $\mathrm{SiO}_{2}$ filma bila je 22,5 $\mu \mathrm{m}$ [15].

\section{Polimerni supstrat}

Supstrat za biomimetsku depoziciju HAP pripremljen je na sledeći način: na staklene pločice nanesen je tanak sloj granula poroznog HAP (dimenzija $300 \mu \mathrm{m}$ ), dobijenog metodom polimernih pena, a zatim su tanki filmovi alginata, celuloze ili PLGA naneti preko apatitnog sloja. Pre nanošenja, alginat i celuloza su rastvoreni u vodi, a PLGA u hloroformu, tako da su dobijeni rastvori koncentracije od $1 \%$. 


\section{Formiranje biomimetskog HAP}

Čelične trake sa deponovanim $\mathrm{SiO}_{2}$ filmom su isečene na deliće, od kojih je jedan deo potopljen u SBF, drugi deo u SBF sa dodatkom FCS, dok je treći deo potopljen u SBF sa dodatkom EMEM. Uzorci su ostavljeni da odstoje u SBF do isteka određenog vremena (10, 14, 20, 33 i 43 dana), pri čemu je dolazilo do samonukleacije HAP na njihovoj površini. Pločice sa nanetim HAP i polimernim filmovima su potom potopljene u SBF i ostavljene da stoje šest nedelja na sobnoj temperaturi. Nakon vađenja iz medijuma uzorci su isprani dejonizovanom vodom, a dobijene faze su analizirane.

\section{Metode karakterizacije nukleiranog HAP}

Nukleirane faze na površini obe vrste supstrata analizirane su metodom FTIR-ATR (Nicollet 380 FT-IR, Thermo Electron Corporation). Morfologija i struktura filmova nukleiranog HAP analizirane su skening-elektronskom mikroskopijom (SEM).

BET metodom je pokazano da debljina filma nukleiranog HAP zavisi od vremena stajanja uzoraka u SBF, kao i od toga što dodatak FCS i EMEM u SBF medijumu utiče na povećanje brzine nukleacije HAP.

\section{REZULTATI I DISKUSIJA}

\section{FTIR analiza}

\section{$\mathrm{SiO}_{2}$ supstrat}

Na slici 1 prikazani su FTIR spektri nukleiranog apatitnog filma nakon različitog vremena držanja uzoraka u SBF. Trake uočljive na spektru na $2340 / \mathrm{cm}$ mogu se pripisati istežućim vibracijama $\mathrm{OH}$-grupa koje se nalaze na krajevima $\mathrm{SiO}_{2}$ lanaca. Trake od 1643/cm do 1649/cm odgovaraju savijajućim vibracijama OH-grupa i iz $\mathrm{SiO}_{2}$ lanaca i iz HAP, a trake na 600/cm do 662/ $\mathrm{cm}$ slobodnim vibracijama OH-grupa. Trake između 1018/cm i 1043/cm odgovaraju transverzalnim asimetričnim vibracijama Si-O-Si lanaca, trake od $791 / \mathrm{cm}$ do $802 / \mathrm{cm}$ pripadaju ljuljajućim vibracijama Si-O-Si lanaca, dok trake od 432/cm do 451/cm odgovaraju transverzalnim ljuljajućim vibracijama ovoga lanaca. Trake koje se pojavljuju na $1018 / \mathrm{cm}$ do $1043 / \mathrm{cm}$ pripadaju asimetričnim istežućim vibracijama $\mathrm{PO}_{4}{ }^{3-}$ grupa, dok trake od $550 / \mathrm{cm} 563 / \mathrm{cm}$ potiču od $v_{2}$ simetričnih istežućih vibracija. Trake od $432 / \mathrm{cm}$ do $451 / \mathrm{cm}$ delom pripadaju $v_{2}$ simetričnim vibracijama $\mathrm{PO}_{4}{ }^{3-}$ grupa [15].

\section{Polimerni supstrat}

Analiziranjem FTIR spektra zaključeno je da je faza formirana biomimetski na površini HAP - polimer kompozita, hidroksiapatit pomerene stehiometrije (Slika 2). Sva tri IR spektra pokazuju trake tipične za HAP: slab vrhunac koji odgovara istezanju OH-grupa uočen je na oko 3570/cm; trake na oko 1640/ $\mathrm{cm}$ odgovaraju savijajućim vibracijama $\mathrm{OH}^{-}$grupa, a trake na $600 / \mathrm{cm}$ do $650 / \mathrm{cm}$ slobodnim vibracijama $\mathrm{OH}^{-}$grupa; trake koje se javljaju na 970/cm do 1090/cm pripadaju asimetričnim istežućim vibracijama $\mathrm{PO}_{4}{ }^{3-}$ grupa, dok trake od 550/cm do $640 / \mathrm{cm}$ potiču od simetričnih istežućih vibracija $\mathrm{PO}_{4}^{3-}$ grupa; trake od $430 / \mathrm{cm}$ do $450 / \mathrm{cm}$ delom pripadaju $v_{2}$ simetričnim vibracijama $\mathrm{PO}_{4}^{3-}$ grupa.

Trake tipične za svaki od polimera se takođe nalaze na odgovarajućim IR spektrima:

- Alginat

Trake koje se nalaze na $3500-3700 / \mathrm{cm}$ pripisuju se istezanju $\mathrm{OH}$-grupa; trake na $1615 / \mathrm{cm}$ i $1420 / \mathrm{cm}$ odgovaraju asimetričnom i simetričnom istezanju $\mathrm{COO}^{-}$grupa; trake na oko $1640 / \mathrm{cm}$ se mogu pripisati vodi vezanoj za polimer; trake na oko 1300/cm odgovaraju vibracijama polimernog lanca; trake koje pripadaju asimetričnom istezanju C-O-C na 1080-1020/ $\mathrm{cm}$ su delimično skrivene trakama koje odgovaraju apatitu; trake koje se nalaze na oko $820 / \mathrm{cm}$ pripisuju se kombinaciji savijajuće vibracije -CCO i -CCH grupa i uvijajuće vibracije $\mathrm{C}=\mathrm{O}$ grupe $[16,17]$.

- Celuloza

Trake na 2920/cm i 2940/cm odgovaraju istezanju C=O i C-H grupa; trake oko $2900 / \mathrm{cm}$ pripadaju O-H istezanju, dok trake na $1640 / \mathrm{cm}$ odgovaraju savijanju O-H iz apsorbovane vode; trake na $1590 / \mathrm{cm}$ potvrđuju postojanje COO-grupe; trake na oko 1430/cm se pripisuju HCH i OCH savijajućim deformacijama u ravni, dok traka na oko $1380 / \mathrm{cm}$ odgovara C-H savijanju; trake na oko 900/cm pripadaju COC, CCO i CCH deformacijama i istežućim vibracijama koje odgovaraju pomeranjima od C-5 i C-6 atoma $[18,19]$.

- PLGA

Trake registrovane na 2995/cm odgovaraju C-H asimetričnom istezanju, dok trake na oko $2950 / \mathrm{cm}$ i $2880 / \mathrm{cm}$ pripadaju C-H simetričnom istezanju; izražena traka na $1760 / \mathrm{cm}$ se pripisuje $\mathrm{C}=\mathrm{O}$ istezanju; trake na $1100-1280 / \mathrm{cm}$ odgovaraju C-O-C istezanju, dok trake uočene od $1400 / \mathrm{cm}$ do $1500 / \mathrm{cm}$ odgovaraju $\mathrm{CH}_{2}, \mathrm{CH}_{3}$ i CH deformacijama; traka na oko $750 / \mathrm{cm}$ pripada ljuljajućim vibracijama dugog $\mathrm{CH}_{2}$ lanca $[20,21]$.

\section{SEM ispitivanja}

\section{$\mathrm{SiO}_{2}$ supstrat}

Na slikama 3a i 3b jasno se vidi način nukleacije apatita sedimentiranjem slojeva do završne debljine apatitnog filma. Uočava se veoma razvijena morfološka struktura nukleiranih čestica, koje su u obliku cveta maslačka i srednjeg prečnika od oko $1 \mu \mathrm{m}$.

\section{Polimerni supstrati}

SEM snimci su pokazali veoma razvijenu morfološku strukturu čestica HAP (Slike 4a-b, 5a-b i 6a-b).

Kao što se uočava na slikama $4 \mathrm{a}$ i $4 \mathrm{~b}$, čestice HAP nukleiranog na alginatu su u obliku cveta maslačka i poligonalnom obliku. Ove potonje su manje, prečnika 1-5 $\mu \mathrm{m}$. Prečnik čestica u obliku maslačka je 3-5 $\mu$ m. Širina igličastih struktura na površini ovih čestica je svega 18-25 nm, dok je rastojanje između njih 150-500 $\mu \mathrm{m}$.

Na slikama 5a i 5b zapaža se raznolikost u morfološkoj strukturi čestica HAP nukleiranog na celulozi. Srednji prečnik čestica je oko $3 \mu \mathrm{m}$, dok su najmanje čestice veličine oko $1 \mu \mathrm{m}$. 
Igličaste i tanjiraste strukture se uočavaju na površini čestica, a njihova širina je 30-150 $\mathrm{nm}$.

Apatit nukleiran na površini PLGA filma prikazan je na slikama 6a i 6b. Čestice su u obliku cveta maslačka s veoma razvijenom morfološkom strukturom površine, na kojoj se nalaze latičaste strukture. Veličina čestica je uglavnom 2,5-3,5 $\mu \mathrm{m}$, ali one nekada mogu biti i sitnije $(0,7-1,5 \mu \mathrm{m})$, odnosno krupnije $(4,3-8,5 \mu \mathrm{m})$. Širina latičastih struktura na površini čestica je $15-20 \mathrm{~nm}$.

\section{Debljina filma nukleiranog HAP}

Na osnovu merenja mase i ukupne zapremine pora metodom Leklua (Lecloux) i Pirara (Pirard), određena je debljina nukleiranih apatitnih filmova [15]. Debljina nukleiranog apatitnog filma zavisi od vremena držanja traka u SBF i od vrste medijuma (Tabela 1).

\section{Mehanizam formiranja HAP}

\section{$\mathrm{SiO}_{2}$ supstrat}

Kada se čelične trake sa $\mathrm{SiO}_{2}$ prevlakama potope u SBF, na njihovoj površini dolazi do samonukleacije HAP. To je uslovljeno prisustvom $\mathrm{Na}^{+}$jona u SBF, koji se inkorporiraju u nanopore $\mathrm{SiO}_{2}$ filma, dovodeći do povećanja lokalne $\mathrm{pH}$ vrednosti na površini filma, što pospešuje heterogenu nukleaciju HAP prema reakciji [22]:

$$
10 \mathrm{Ca}^{2+}{ }_{(\mathrm{aq})}+6 \mathrm{PO}_{4}^{3-}{ }_{(\mathrm{aq})}+2 \mathrm{OH}_{(\mathrm{aq})}^{-}=\mathrm{Ca}_{10}\left(\mathrm{PO}_{4}\right)_{6}(\mathrm{OH})_{2(\mathrm{~s})} .
$$

Najpre pozitivni $\mathrm{Ca}^{2+}$ joni bivaju privučeni na površinu $\mathrm{SiO}_{2}$ filma usled postojanja Si-OH grupa, a zatim privučeni i negativno naelektrisani $\mathrm{PO}_{4}{ }^{3-}$ joni, što dovodi do formiranja kalcijum-fosfata. Kada se HAP stvori na površini $\mathrm{SiO}_{2}$ filma, dalja nukleacija se dešava spontano, jer je energija aktivacije za heterogenu nukleaciju na površini manja od energije aktivacije za homogenu nukleaciju u rastvoru [23]. Dalje dolazi do rasta nukleiranog apatitnog filma uz istovremeno privlačenje kalcijumovih i fosfatnih jona iz SBF.

Dodatkom FCS iEMEM u SBF, pored nukleacije, čiji je mehanizam već opisan, značajan je i uticaj amino-grupa u FCS i delova naelektrisanih proteina u EMEM. Oni deluju kao dodatni i vrlo efikasni centri nukleacije svojim polarnim dejstvom, i po mehanizmu PILP (engl. polymer induced liquid precursor - tečni prekursor indukovan polimerom) uslovljavaju ubrzanu nukleaciju apatita kroz proces vezivanja $\mathrm{Ca}^{2+}$ na datim aktivnim centrima, a potom simultanim vezivanjem $\mathrm{PO}_{4}{ }^{3-}$ jona.

\section{Polimerni supstrati}

Karboksilne i hidroksilne grupe iz alginatnih, celuloznih i lanaca PLGA deluju kao aktivni centri koji iniciraju nukleaciju. Ove negativno naelektrisane grupe, u početnoj fazi nukleacije privlače $\mathrm{Ca}^{2+}$ jone iz SBF, koji potom bivaju nakačeni na površinu polimera. U sledećem koraku $\mathrm{PO}_{4}{ }^{3-}$ joni bivaju privučeni od pozitivnih $\mathrm{Ca}^{2+}$ jona. Proces nukleacije kalcijum-fosfata dalje se odigrava „kačenjem” Ca ${ }^{2+}$ jona na aktivna mesta odgovarajućeg polimera i simultanim "kačenjem” $\mathrm{PO}_{4}{ }^{3-}$ jona na $\mathrm{Ca}^{2+}$ jone. Kao što je pokazano u nekim studijama, koncentracija karboksilnih i hidroksilnih grupa na površini polimera najverovatnije značajno utiče na brzinu i mehanizam nukleacije kalcijum-fosfata [24, 25].

Gustina nukleacionih mesta može takođe da utiče na veličinu aglomerata i njihovu morfološku strukturu, što potvrđuju i rezultati dobijeni u ovom radu. Najveća gustina nukleiranih čestica uočena je pri korišćenju alginata (Slika 4a-b), što je verovatno uslovljeno velikom gustinom karboksilnih i hidroksilnih grupa u alginatnim lancima. U slučaju nukleacije na PLGA (Slika 6a-b), koji sadrži znatno manji broj karboksilnih grupa nego alginat, relativno je manja gustina nukleiranih čestica. Posmatrajući prostorni raspored hidroksilnih grupa u celuloznim lancima, može se videti da su relativno blizu jedna drugoj. Stoga se verovatno aglomerati sa susednih nukleacionih mesta spajaju formirajući izdužene strukture (Slika 5a-b). Takođe, u uzorcima gde su korišćeni alginat i celuloza dobijene su manje čestice (1-5 $\mu \mathrm{m})$, što može biti posledica velikog broja nukleacionih mesta, dok su u slučaju PLGA dobijeni veći aglomerati (neki prečnika većeg od $8 \mu \mathrm{m}$ ), što se može pripisati manjem broju nukleacionih mesta koja uslovljavaju dalji rast apatitnog nukleusa.

\section{ZAKLJUČAK}

U ovom radu pokazana je mogućnost dobijanja biomimetskog HAP samonukleacijom na različitim supstratima uz zastupljenost SBF. I u slučaju $\mathrm{SiO}_{2}$ kao supstrata, i u slučaju kada su korišćeni polimerni filmovi naneseni na porozni apatitni nosač, FTIR-ATR metodom potvrđeno je postojanje HAP na njihovoj površini posle određenog vremena držanja u SBF. SEM analizom utvrđena je struktura samonukleiranog apatitnog filma. Merenjem mase uz korekcije zapremine metodom BET pokazano je da debljina nukleiranog filma zavisi od vremena držanja traka u SBF, kao i da dodatak FCS i EMEM medijuma ubrzava proces samonukleacije apatitnog filma.

\section{NAPOMENA}

Izradu ovoga rada finansijski je podržalo Ministarstvo za nauku i tehnološki razvoj Republike Srbije (Projekat br. 172026). 